Background: Mastectomy, a procedure carried out to save life in women with breast cancer, is a huge burden as a result of the feeling of lethal threat, mutilation and anxiety of social exclusion.

The objective was to assess the level of depression in members and non-members of the Amazons Club (AC), to assess the relationship between level of depression and membership in AC, and to assess the importance of benefits for AC members.

Material and methods: The study included 101 women (50 members and 51 non-members of the $A C$ ), who were interviewed using a structured questionnaire. Depression was measured using the Center for Epidemiological Studies Depression Scale (CES-D).

Results: $78 \%$ of AC members highly assessed the benefits (psychological support, access to expertise, social meetings) of membership in this organization. The proportion of depression was lower among women belonging to the AC (14 vs. $36 \%, p<0.05)$. A significant difference in the average level of depression was observed and it was lower among women belonging to the $A C$ (9.6) than women not belonging to the $\mathrm{AC}(14.3)(p<0.05)$. Membership in the AC was not significantly associated with a reduction in the level of depres sive symptoms in the entire group, after adjustment for covariates.

Conclusions: Despite the very positive assessment of membership and broad participation in the activities offered by the $A C$, there was no significant association between membership in the $A C$ and the level of depression in women after mastectomy.

Key words: breast cancer, mastectomy, depression, Amazons Club, social support, peer-support organization.

\section{Membership in a breast cancer peer-support organization (Amazons Club) and depression}

\author{
Magdalena Kozela, Urszula Stepaniak, Andrzej Pająk
}

Department of Epidemiology and Population Studies, Institute of Public Health, Jagiellonian University Medical College, Krakow

\section{Introduction}

Depression affects about $42 \%$ of women with breast cancer [1]. Breast cancer is one of the top three tumours in which depression is the most prevalent (after pancreatic cancer and brain tumours) [2]. Among patients with breast cancer depression is most common in women after mastectomy [3]. The relation between social support and occurrence of depression is well evidenced $[4,5]$, as is the association between anger at the lack of social support and depression [6]. In cancer patients, social bonds are the source of feeling that life is stable and predictable. They also help to reduce anxiety, feelings of helplessness, and depression [7]. A special kind of support for women after mastectomy is offered by peer-support organizations - Amazons Clubs (AC). The essence of such an organization is provision of help by people struggling with the same problem [8]. Support provided by peer-support groups is unique and unavailable from any other source [9]. The AC's objective is to help women deal with the difficult situation and to enable members to achieve the best physical and mental health.

Membership in the AC can therefore play an important role in preventing or reducing depressive symptoms after mastectomy. In the literature there are very few studies evaluating the effectiveness of the AC in reducing depressive symptoms. This paper had the following objectives:

- to assess the level of depression in members and non-members of AC;

- to assess the relationship between the level of depression and membership in the AC;

- to assess the importance of benefits for AC members.

\section{Material and methods}

Studied group

The studied group included 101 women after radical surgical treatment of breast cancer. Out of them 50 belonged to the AC (AC group) and 51 did not belong to the AC (control group). The AC group consisted of women participating in at least one of three regular AC meetings which took place in the Cracow Society of the Amazons at the Institute of Oncology from April to June 2009 or who appeared in the AC during that period for any other purposes. The control group consisted of consecutive patients of the out-patient clinic of the Department of Gynaecology and Oncology and the out-patient clinic of the Department of Clinical Oncology, University Hospital, Jagiellonian University Medical College in Krakow.

\section{Method}

Screening was conducted using a structured questionnaire using the Center for Epidemiological Studies Depression Scale (CES-D). Depression was diagnosed if the score on the scale was equal to 16 points or more [10].

The methods of statistical analysis included: descriptive statistics, $\chi^{2}$ test, t-test and Mann-Whitney $U$ test. Analysis of covariance was used to com- 
pare means with standardization for age. The main statistical method was analysis of linear regression. Univariate regression models were designed to establish the relationship between various risk factors associated with depression and the level of depressive symptoms expressed as the number of points according to the CES-D scale. Then, multivariate models were created to assess the relationship between membership in the AC (independent variable) and the level of depressive symptoms (dependent variable), with adjustment for age and education, and subsequently variables significantly associated with the level of depressive symptoms were included in univariate models. Analyses were performed using the STATISTICA statistical package, version 8.0.

\section{Results}

Complete data were collected from 100 patients (50 women belonging to the $\mathrm{AC}$ and 50 women not belonging to the $\mathrm{AC}$ ). One person from the control group refused to take part in the study. The mean age did not differ significantly between groups and in the AC group was 60.4 years $(S D=10.4$ years), and the control group 56.9 years $(\mathrm{SD}=10.2$ years). Women belonging to the $\mathrm{AC}$ had a higher education level, more often lived in the city, and were significantly less likely to have a regular partner compared to women not belonging to the AC (table 1). Among AC members a higher percentage of women maintained informal contacts with other women after mastectomy (80 vs. $34 \%$, $p<0.001) .72 \%$ of AC members were more than 5 years

Table 1. Sociodemographic characteristics of members and nonmembers of Amazons Club

\begin{tabular}{|c|c|c|c|c|c|}
\hline & \multicolumn{2}{|c|}{$\begin{array}{l}\text { Members } \\
N=50\end{array}$} & \multicolumn{2}{|c|}{$\begin{array}{l}\text { Non-members } \\
\qquad N=50\end{array}$} & \multirow[t]{2}{*}{$p$} \\
\hline & $n$ & $\%$ & $n$ & $\%$ & \\
\hline $\begin{array}{l}\text { Education } \\
\text { primary or vocational } \\
\text { secondary } \\
\text { university }\end{array}$ & $\begin{array}{l}11 \\
24 \\
15\end{array}$ & $\begin{array}{l}22 \\
48 \\
30\end{array}$ & $\begin{array}{l}15 \\
25 \\
10\end{array}$ & $\begin{array}{l}30 \\
50 \\
20\end{array}$ & $<0.05$ \\
\hline $\begin{array}{l}\text { Place of residence } \\
\text { urban } \\
\text { rural }\end{array}$ & $\begin{array}{c}46 \\
4\end{array}$ & $\begin{array}{c}92 \\
8\end{array}$ & $\begin{array}{l}33 \\
17\end{array}$ & $\begin{array}{l}66 \\
34\end{array}$ & $<0.01$ \\
\hline Having a permanent partner & 25 & 50 & 36 & 72 & $<0.05$ \\
\hline Having children & 36 & 72 & 44 & 88 & NS \\
\hline
\end{tabular}

Table 2. Participation by club members in activities offered by Amazons Club

\begin{tabular}{|lcc|} 
& \multicolumn{3}{c}{$N=50$} \\
& $n$ & $\%$ \\
\hline special events & 43 & 86 \\
\hline regular meetings & 38 & 76 \\
\hline gymnastics & 32 & 64 \\
information about the supply of breast & 20 & 40 \\
prostheses and special lingerie & & \\
\hline psychological counselling & 8 & 16 \\
\hline
\end{tabular}

after mastectomy, vs. only $32 \%$ in the control group. In that group 20\% were less than one year after surgery $(p<0.001)$.

The main source of information about the possibility of joining the AC were Amazons Volunteers (60\%) and medical personnel at the hospital where the patient underwent surgery (20\%). Fewer patients received the information from friends (16\%) or brochures and leaflets (4\%).

Of all the activities offered by the AC women most often chose regular meetings, special events and gymnastics. Relatively few respondents used counselling with a psychologist (table 2). The majority of respondents (78\%) rated highly or very highly psychological support received in the AC, access to expertise concerning the disease, and opportunities for socializing. Slightly fewer respondents (64\%) rated highly the help in solving practical problems associated with the disease.

The prevalence of depression was significantly lower in AC members as compared with women who did not belong to the AC (respectively $14 \%$ and $36 \%, p<0.05$ ). The average level of depression, expressed as the number of points on the CES-D scale, was significantly lower in the group of women belonging to the $A C$ than in the group of women not belonging to the AC (9.6 and 14.2, respectively $p<0.05$ ). The significant difference remained after adjustment for age.

Membership in the AC was significantly negatively associated with levels of depressive symptoms after adjustment for age, education, and receiving family support. However, after taking into account the impact of other confounders, such as receiving support of religion, place of residence, depression before cancer diagnosis, time since the mastectomy, and the occurrence of stressful life events in the past 6 months, membership in the AC was not significantly related to the level of depressive symptoms (table 3 ).

\section{Discussion}

In the present study the prevalence of depression in women after mastectomy was high (36\%) in the group of women who did not belong to the AC. In the group of AC

Table 3. Relationship between membership in Amazons Club and level of depression - multiple regression models

\begin{tabular}{|lcc|}
\hline $\begin{array}{l}\text { Variables in analysis } \\
\text { age, education }\end{array}$ & $\mathrm{B}(95 \% \mathrm{Cl})$ \\
\hline $\begin{array}{l}\text { age, education, receiving } \\
\text { family support }\end{array}$ & $-4.27(-8.097$ to -0.452$)$ & 0.057 \\
\hline $\begin{array}{l}\text { age, education, receiving } \\
\text { support of religion }\end{array}$ & $-3.78(-7.56$ to 0.001$)$ & 0.09 \\
\hline $\begin{array}{l}\text { age, education, place of }-0.721) \\
\text { residence }\end{array}$ & $-3.74(-7.75$ to 0.27$)$ & 0.10 \\
\hline $\begin{array}{l}\text { age, education, depression } \\
\text { before cancer diagnosis }\end{array}$ & $-3.64(-7.48$ to 0.21) & 0.08 \\
\hline $\begin{array}{l}\text { age, education, time since } \\
\text { mastectomy }\end{array}$ & $-3,58(-7.44$ to 0.28$)$ & 0.08 \\
\hline $\begin{array}{l}\text { age, education, stressful life } \\
\text { events in last 6 months }\end{array}$ & $-3.22(-6.86$ to 0.42) & 0.17 \\
\hline
\end{tabular}


members depression was significantly lower (14\%). Although membership in the AC was negatively associated with increased levels of depression, adjusting for age, education and family support, after adjustment for other covariates, i.e. receiving religion support, place of residence, depression before the cancer diagnosis, time since mastectomy, and the occurrence of stressful life events in the last 6 months, the relationship was statistically insignificant.

The results of other studies on the relationship between membership in peer-support organizations and depression are inconclusive. Peer-support group membership was associated with lower levels of depression in the studies of Stevens and Duttlinger [11] and Montazeri [12], while in the study of Jacobs et al. [13] it did not show such a relationship. In the study of MacArdle et al. [14] the level of depression was significantly lower in women under the care of trained nurses than in a peer-support group organized by volunteers.

The fact that the association between membership in the $A C$ and the level of depressive symptoms was not confirmed in our study does not mean that in the other $A C$ in Poland, such an association could not exist. However, a search of the Polish Medical Bibliography for the years 1991-2009, using the keywords peer-support groups, selfhelp, social support, efficacy, Amazons Club, mastectomy, depression, and mental state examination scale, did not result in finding other evidence of such a relation.

In this study nearly $80 \%$ of women belonging to the $\mathrm{AC}$ highly rated the benefits of membership. Most important for the surveyed women were: psychological support, access to expertise concerning the disease, and social events. In a study of Skrzypulec et al., 51\% of AC members claimed that they had not received sufficient support from the AC or that activity proposed in the AC should not be treated in terms of support [15]. In our study, women who belonged to the AC often participated in regular meetings, gymnastics and special events. In the study of Wybraniec-Lewicka et al., most women declared that they attended gymnastics and classes at the swimming pool [16]. In the above study more women participated in meetings with a psychologist, while in our study women rarely used psychological counselling. AC membership in the Polish Federation of Clubs for Women after Mastectomy requires common objectives, but the methods to achieve them may be different and depend mainly on local conditions, infrastructure, financial resources available, as well as charisma of the leading personnel. Clubs in different sites have different activity profiles, the main differences being in organization and content of regular meetings and psychologist counselling.

In the present study standard methods of observation were used. Recruitment to the sample was accomplished through the inclusion of all consecutive cases coming to the $\mathrm{AC}$ and to the clinic. Only one of all invited women refused to participate, so the problem of non-respondents almost did not exist. The study was conducted in the spring and summer in order to eliminate the influence of seasonal depression. However, there are some limitations in interpreting the results. The study was cross-sectional, so one can make conclusions about a possible causal relationship between variables. Lower levels of depression in AC members may be the result of help in recovering from depression, but also may be an effect of more active seeking of help, participation in social life and membership in the AC by less depressed women. Higher levels of depression may contribute to social exclusion, and therefore also to nonparticipation in organizations such as the AC. This work does not provide the evidence, but it cannot be excluded that the difference in the level of depression among AC members and non-members could partially be explained by the fact that women belonging to the AC had a lower initial level of depression and a smaller burden of stressful life events.

Furthermore, due to the design of the study, the groups were not fully comparable in terms of characteristics such as education, place of residence, or having a permanent partner. The small size of the study group is linked to the low statistical power. This could affect the final results after adjustment for confounders.

In conclusion, it can be assumed that the relationship between membership in the AC and the level of depression is weaker than expected. However, the AC does not exist only in order to improve mental health of women after mastectomy. Membership can be perceived as a means of social rehabilitation. The Law on Vocational Rehabilitation and Employment of Disabled [17] is aimed at enabling people with disabilities to participate in society by encouraging social activity, shaping the right attitudes and behaviours conducive to integration, and creating a proper attitude towards groups of disabled, through social pressure groups. By meeting in the AC, women can become members of social groups, make contacts, and avoid social exclusion, which is a real threat for every woman after mastectomy. The results of this study provide inspiration for assessing the impact of the $A C$ on quality of life of women after mastectomy in more detail and on a larger scale, including the areas of both mental health and social functioning.

\section{References}

1. Trzebiatowska IA. Leczenie depresji w chorobie nowotworowejaspekty praktyczne. Psychoonkologia 1999; 4: 47-52.

2. Krzakowski M. Rak piersi - charakterystyka problemu zdrowotnego: Stowarzyszenie Kobiet z Problemem Onkologicznym, Tom 1. Biuletyn 2008; 54.

3. Golden Kreutz DM, Andersen L. Depressive symptoms after Brest cancer surgery: relationships with global, cancer-related, and life event stress. Psychooncology 2004; 13: 211-20.

4. Piwoński J, Piwońska A, GłuszekJ, Kielecki W, Pająk A, Kozakiewicz K, Wyrzykowski B, Rysik S. Ocena częstości występowania niskiego poziomu wsparcia społecznego oraz objawów depresji w populacji polskiej. Wyniki programu WOBASZ; Kardiol Pol 2005; 63: 645-8.

5. Jané-Llopis E, Anderson P. Mental Health Promotion and Mental Disorder Prevention. A Policy for Europe. Radboud University Nijmegen, Nijmegen 2005

6. Pasikowski T. Stres i zdrowie. Wydawnictwo Fundacji Humanitora, Poznań 2000.

7. Sęk H, Cieślak, R. Wsparcie społeczne - sposoby definiowania, rodzaje i źródła wsparcia, wybrane koncepcje teoretyczne, Wsparcie społeczne, stres i zdrowie. Sęk H, Cieślak R (red.). PWN, Warszawa 2004; 11-28. 
8. Michalska Z. Istota działalności Federacji Polskich Klubów Kobiet po Mastektomii „Amazonki” - Konferencja Przewodniczących Klubów i Filii. 29.08.1998. Nasze życie 1999; 13.

9. Widera A. Grupa wsparcia pacjentów ze stomią - rola, zadania, zasady funkcjonowania, II spotkania otwarte żyj z chorobą nowotworową - materiały naukowe. Wordliczek J, Czupryna A (red). UNICORN, Kraków 2003.

10. Radloff LS. The CES-D scale: A self-report depression scale for research in the general population. Appl Psych Meas 1977; 3: 385-401.

11. Stevens MJ, Duttlinger JE. Correlates of participation in a breast cancer support group. J Psychosom Res 1998; 45: 263-75.

12. Montazeri A, Jarvandi S, Haghighat S, Vahdani M, Sajadian A, Ebrahimi M, Haji-Mahmoodi M. Anxiety and depression in beast cancer patients before and after participation in a cancer suport group, Patient Educ Couns 2001; 45: 195-8.

13. Jacobs C, Ross RD, Walker IM, Stockdale FE. Behaviour of cancer patients: a andomized study of the effects of education and peer support groups. Am J Clin Oncol (CCT) 1983; 6: 347-50.

14. McArdle JM, George WD, McArdle CS, Smith DC, Moodie AR, Hughson AV, Murray G.D., al. Psychological support for patients undergoing breast cancer surgery: a randomised study. Brit Med J 1996; 312: 813-6.

15. Skrzypulec V, Tobor E, Drosdzol A, Nowosielski K. Biopsychosocial functioning of women after mastectomy. J Clin Nurs 2009; 18: 613-9.

16. Wybraniec-Lewicka B, Springer M, Czerwiak G, Michalska M, Ciura E. Styl życia kobiet po mastektomii. Studia Medyczne 2008; 10: 27-30.

17. Ustawa z dnia 27 sierpnia 1997 r. o rehabilitacji zawodowe i społecznej oraz zatrudnianiu osób niepełnosprawnych. Dz. U. 97.123 .776 z późn. zm.

\section{Address for correspondence}

\section{Magdalena Kozela}

Department of Epidemiology and Population Studies Institute of Public Health

Grzegórzewska 20

31-501 Krakow

Jagiellonian University

Collegium Medicum

e-mail: mmkozela@gmail.com 